\title{
Redefining Gonadotropin-Releasing Hormone (GnRH) Cell Groups in the Male Syrian Hamster: Testosterone Regulates GnRH mRNA in the Tenia Tecta
}

\author{
Heather N. Richardson,* David B. Parfitt, † Robert C. Thompsonł and Cheryl L. Sisk* \\ *Department of Psychology and Neuroscience Program, Michigan State University, East Lansing, MI 48824, USA. \\ $\dagger$ † Department of Biology and Neuroscience Program, Middlebury College, Middlebury, VT 05753, USA. \\ \$Department of Psychiatry and Reproductive Science Program, University of Michigan, Ann Arbor, MI 48109-0512, USA.
}

Key words: LHRH, GnRH mRNA, testosterone, tenia tecta, hamster.

\begin{abstract}
Gonadotropin-releasing hormone $(\mathrm{GnRH})$ regulates the production of testosterone via the hypothalamic-pituitary-gonadal axis and testosterone, in turn, regulates the GnRH system via negative feedback. We compared testosterone regulation of $\mathrm{GnRH}$ mRNA expression in four anatomically defined $\mathrm{GnRH}$ cell groups in juvenile and adult male Syrian hamsters, including a rostral population of $\mathrm{GnRH}$ cells in the tenia tecta. In situ hybridization histochemistry (ISHH) was used to measure $\mathrm{GnRH}$ mRNA in brains from castrated juveniles and adults treated with $0 \mathrm{mg}$ or $2.5 \mathrm{mg}$ testosterone pellets for one week. ISHH was performed on coronal sections using a ${ }^{35} \mathrm{~S}$-cRNA probe generated from Syrian hamster GnRH cDNA. Testosterone treatment resulted in a significant reduction in mean area of $\mathrm{GnRH}$ neurones covered by silver grains within the tenia tecta, but only a trend toward decreased GnRH mRNA in the diagonal band of Broca/organum vasculosum of the lamina terminalis (DBB/OVLT), medial septum (MS), and caudal preoptic area (CPOA). The effects of testosterone were independent of age. Frequency distribution analyses unveiled a significant reduction in the number of heavily labelled cells following testosterone treatment within the tenia tecta and MS. Simple regression analyses revealed a significant positive correlation between plasma luteinizing hormone concentrations and $\mathrm{GnRH}$ mRNA only in the tenia tecta. These data indicate that, overall, GnRH mRNA is modestly reduced by testosterone, and the most robust attenuation of $\mathrm{GnRH}$ mRNA occurs within the tenia tecta. This is the first report to link mechanisms of steroid negative feedback with tenia tecta $\mathrm{GnRH}$ neurones, providing a new focus for investigating brain region-specific steroidal regulation of $\mathrm{GnRH}$ synthesis.
\end{abstract}

\section{Introduction}

Gonadotropin-releasing hormone $(\mathrm{GnRH})$ regulates the production of testicular steroids via the hypothalamicpituitary-gonadal (HPG) axis. Testosterone, in turn, regulates the GnRH neuronal system via negative feedback. The threshold for steroid negative feedback regulation of the HPG axis varies with reproductive status. Responsiveness to negative feedback is particularly high prior to puberty in many species. For example, in hamsters, when testosterone is experimentally clamped at physiological levels in juvenile males, gonadotropin secretion is completely suppressed. However, as the males enter puberty, plasma concentrations of gonadotropin rise despite the constantly maintained levels of testosterone (1). Thus, a change in the negative-feedback set point is involved in the pubertal rise in gonadotropin secretion in hamsters.

The cellular mechanisms underlying negative-feedback inhibition of GnRH neuronal activity are not well understood, nor is it known if they change during development. One reason for this lack of understanding is related to the diffuse distribution of GnRH neurones throughout the forebrain,

Correspondence to: Heather N. Richardson, Neuroscience Program, Michigan State University, East Lansing, MI 48824 (e-mail: richa199@msu.edu). 
a feature that makes it difficult to study the system as a whole. Since GnRH neuronal phenotype and afferents vary with brain region (2-5), the cellular level at which steroids regulate $\mathrm{GnRH}$ neurones may also vary with brain region.

In the Syrian hamster (Mesocricetus auratus) and other rodents, GnRH cell bodies reside primarily in rostral forebrain regions, including the diagonal band of Broca/organum vasculosum of the lamina terminalis (DBB/OVLT), medial septum (MS), and caudal preoptic area (cPOA, 6-9). Within these brain regions, GnRH cell bodies are not aggregated closely together. A small and somewhat more clustered population of GnRH neurones embedded within a plexus of $\mathrm{GnRH}$ fibres is located within the tenia tecta of the rostral forebrain (Fig. 1). Little is known about tenia tecta $\mathrm{GnRH}$ neurones, but they appear to be activated by sensory stimuli to produce the preovulatory luteinizing hormone $(\mathrm{LH})$ surge in the musk shrew, a reflex ovulator (10-12).

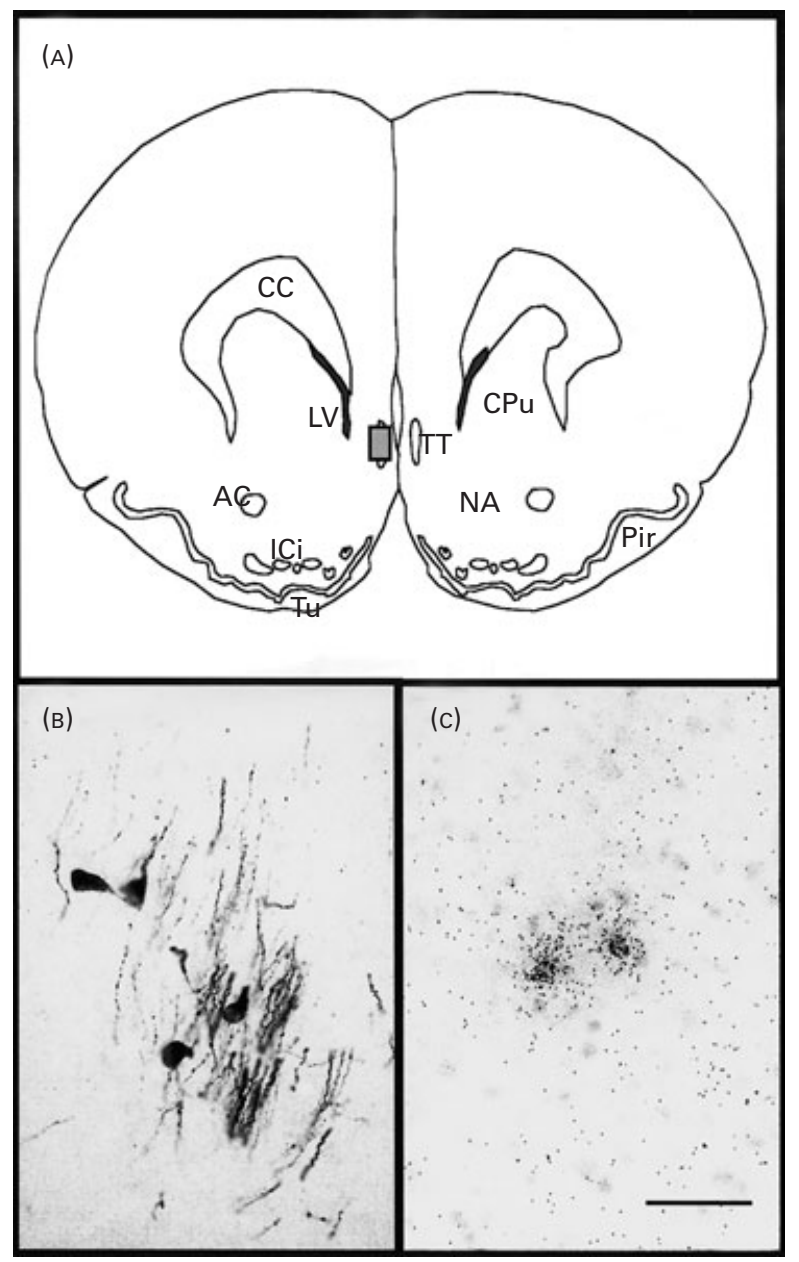

FIG. 1. (A) Drawing of an anatomical section [adapted from (18)] delineating the location of GnRH cells in the tenia tecta (shaded box). (в) GnRH-immunoreactive cells and fibers in the tenia tecta [see (8) for details on GnRH immunocytochemistry methods]. (c) GnRH-mRNA labelled cells in the tenia tecta. Differences in section thickness $(40 \mu \mathrm{m}$ for immunocytochemistry $v s 10 \mu \mathrm{m}$ for ISSH) likely account for the different number of cells in the two photomicrographs. Bar, $50 \mu \mathrm{m}$.
Regulation of GnRH mRNA is one cellular level at which steroids exert feedback effects on the HPG axis. The effects of steroids on GnRH mRNA are brain region-dependent (13-16). Thus, the goals of the current experiment were twofold (1): to conduct a brain regional analysis of testosterone regulation of GnRH mRNA in which tenia tecta $\mathrm{GnRH}$ neurones are distinguished from those in other brain regions, and (2) to determine whether a change in the specific cell groups in which GnRH mRNA expression is decreased by testosterone is a correlate of the pubertal decrease in steroid negative feedback. In situ hybridization histochemistry was performed to measure GnRH mRNA in four GnRH cell populations in testosterone-treated gonadectomized juvenile and adult male Syrian hamsters. We provide evidence for the first time that GnRH mRNA expression in neurones in the tenia tecta is reduced by testosterone in both juvenile and adult males. While GnRH mRNA expression is only modestly regulated by testosterone overall in the brain, this regulation is most pronounced in tenia tecta neurones.

\section{Methods \\ Animals, experimental design and tissue collection}

One day after arrival from Charles River (Kingston, NY, USA), 12 prepubertal (23 days old) and 12 adult (60 days old) male Syrian hamsters (Mesocricetus auratus) were anaesthetized with methoxyflurane (Metofane, Mallinckrodt Veterinary Inc., Mundelein, IL, USA), castrated, and implanted subcutaneously with either a placebo (blank) or a $2.5-\mathrm{mg}$ timed-release testosterone pellet $(n=6$ per treatment group, Innovative Research, Sarasota, FL, USA). Following treatment, all animals were singly housed in clear polycarbonate cages $(37.5 \times 33 \times 17 \mathrm{~cm})$ with wood chips (Aspen Chip Laboratory Bedding, Warrensburg, NY, USA). Throughout the experiment room temperature was maintained at $21 \pm 2{ }^{\circ} \mathrm{C}$ and the light-dark schedule was $14 \mathrm{~h}$ light $/ 10 \mathrm{~h}$ dark (lights on at $0600 \mathrm{~h}$ EST). Hamsters had ad libitum access to rodent chow (Teklad Rodent Diet no. 8640, Harlan, Madison, WI, USA) and water throughout the study. Hamsters were treated in accordance with the NIH Guide for the Care and Use of Laboratory Animals and protocols were approved by the Michigan State University All-University Committee for Animal Use and Care.

Seven days following gonadectomy and steroid treatment (at 30 or 67 days old), hamsters were anaesthetized with Metofane and decapitated. Trunk blood was collected for measurement of plasma concentrations of testosterone and LH. Brains were rapidly removed and snap frozen in an isopentane/dry ice bath. Frozen brains were stored at $-80{ }^{\circ} \mathrm{C}$ until sectioning on the cryostat. Every other coronal section $(10 \mu \mathrm{m})$ was collected and thaw-mounted onto poly L-lysine coated slides to produce a total of four sets. Slides were stored with desiccant at $-80{ }^{\circ} \mathrm{C}$ until in situ hybridization histochemistry was performed.

\section{GnRH $m R N A$ in situ hybridization histochemistry}

One set of sections from each brain was processed for in situ hybridization using a ${ }^{35} \mathrm{~S}$-cRNA probe generated from Syrian hamster GnRH cDNA (generously donated by Dr Heiko Jansen, Washington State University, USA). The antisense probe was transcribed in a reaction mixture containing $1 \mathrm{Fg}$ of linearized DNA (BamH I linearized plasmid), $5 \times$ transcription buffer (Epicentre Technologies, Madison, WI, USA), $80 \mu \mathrm{Ci}\left[{ }^{35} \mathrm{~S}\right] \mathrm{UTP}, 120 \mu \mathrm{Ci}$ $\left.{ }^{35} \mathrm{~S}\right] \mathrm{CTP}, 150 \mu \mathrm{M}$ ATP, $150 \mu \mathrm{M}$ GTP, $12.5 \mathrm{mM}$ dithiothreitol, 20 U RNAse inhibitor, and 6 U T7 RNA polymerase (Epicentre Technologies). Following an incubation at $37^{\circ} \mathrm{C}$ for $2 \mathrm{~h}$, unincorporated nucleotides were separated by Sephadex G50-50 chromatography and the antisense probe diluted in $50 \%$ hybridization buffer (Amresco, Solon, OH, USA) to obtain $\sim 1.0 \times 10^{6}$ $\mathrm{CPM} / 70 \mu \mathrm{l}$ of buffer. Slides were removed from the $-80{ }^{\circ} \mathrm{C}$ freezer and placed immediately in $4 \%$ paraformaldehyde for $1 \mathrm{~h}$. They were then washed several times in $2 \times \mathrm{NaCl} / \mathrm{Na}$ citrate (SSC) before a 10 -min incubation in $0.1 \mathrm{M}$ triethanolamine (TEA) containing $0.25 \%$ acetic anhydride. Slides were washed in $\mathrm{dH}_{2} \mathrm{O}$ and dehydrated through a series of alcohols. 
Diluted probe $(70 \mu \mathrm{l})$ was applied onto each slide and a glass coverslip was gently placed over the sections to prevent evaporation of the probe during hybridization. Slides were placed in plastic boxes lined with filter paper saturated with $50 \%$ formamide. The boxes were covered with plastic lids, wrapped with plastic wrap, and incubated at $55^{\circ} \mathrm{C}$ for $16 \mathrm{~h}$. Following hybridization, the coverslips were removed by washes in $2 \times \mathrm{SSC}$ and the slides were then incubated in RNAse A buffer $(200 \mu \mathrm{g} / \mathrm{mL})$ for $1 \mathrm{~h}$ at $37^{\circ} \mathrm{C}$. This incubation was followed by several washes in decreasing concentrations of SSC $(2 \times, 1 \times, 0.5 \times$, and $0.1 \times)$ and an incubation in $0.1 \times$ SSC for $1 \mathrm{~h}$ at $70{ }^{\circ} \mathrm{C}$. Afterwards, slides were washed in $0.1 \times \mathrm{SSC}$ and $\mathrm{dH}_{2} \mathrm{O}$ rinses, dehydrated in graded alcohols, and air-dried. Once completely dry, slides were exposed to XAR film (Eastman Kodak, Rochester, NY, USA) for 14 days. After removal from film, they were emulsion-dipped (NTB2 emulsion from Eastman Kodak diluted 1:1 in distilled water), stored in lighttight boxes at $4{ }^{\circ} \mathrm{C}$ for 3 days, and developed using standard procedures (17) for microscopic analysis of silver grains. Sections were then lightly counterstained with thionin to visualize cell bodies, dehydrated in alcohols, cleared, and coverslipped. Incubation of tissue sections with a sense probe does not result in labelling of cells (17).

\section{Redefining GnRH subpopulations and microscopic analysis}

For the brain regional analysis, GnRH cells were divided into more specific subpopulations than in our previous studies $(8,17)$. Closer inspection of a library of brain sections processed for GnRH-immunoreactivity revealed a distinct population of GnRH cells in the tenia tecta (Fig. 1) (8, 19). Tenia tecta GnRH neurones may be the same as those described in or near the hippocampal rudiment in previous studies of the GnRH system in the hamster (7). These cells are notable in that they appear more closely associated with both each other and a plexus of GnRH fibres (Fig. 1B) than are GnRH cells in other brain regions. We therefore collected more anterior brain tissue in the current study than in previous studies $(8,17)$ in order to include all $\mathrm{GnRH}$ cells within the tenia tecta in the present analysis. Altogether, four populations of GnRH neurones were analysed: tenia tecta, DBB/OVLT, MS, and cPOA These brain regions are operationally defined in Fig. 2.

All analyses were carried out by one investigator blind to the treatment conditions using a Leitz Laborlux S microscope equipped with a CCD video camera (Sony, XC-77). Labeled cells were located under darkfield microscopy at $100 \times$ or $200 \times$ magnification and then were analysed individually at a magnification of $400 \times$ in brightfield microcopy. Images were captured through a blue no. 47 filter used to subtract Nissl staining (Tiffen, Hauppauge, NY, USA), and analysed using NIH Scion Image 1.57 on a Power Macintosh 7100 computer. Each cell profile was first traced and Nissl area was measured. After the cell profile was traced and Nissl area measured, a threshold was set so that only silver grains were visualized, and the area $\left(\mu \mathrm{m}^{2}\right)$ covered by silver grains was measured. Although silver grains over intensely labelled cells were not confined to the Nissl boundary, we quantified only silver grain labelling over Nissl stain because it provided an objective definition of the cell. Thus, this measurement is a conservative estimate of the amount of silver grain labelling associated with the cell. The cell tracing was then moved to a nearby area without specific hybridization to determine background silver grain area A GnRH-mRNA expressing cell was defined as a cell in which the area covered by silver grains was $\geq 5 \times$ that of background. Background grain area was subtracted from the Nissl cell grain area to obtain GnRH mRNA grain area for individual cells. The silver grain area of all cells within each brain region was averaged for each animal. Finally, mean silver grain area for each region was averaged across animals within each treatment group to obtain mean sliver grain area for the tenia tecta, MS, DBB/OVLT, and cPOA.

\section{Radioimmunoassays}

Plasma testosterone concentrations were measured in duplicate samples using the Coat-A-Count Total Testosterone Kit (Diagnostic Products, Los Angles, CA, USA). This radioimmunoassay (RIA) has been validated in our laboratory for the measurement of plasma testosterone concentrations in Syrian hamsters (17). The lower limit of detectability was $0.1 \mathrm{ng} / \mathrm{mL}$ and the intra-assay coefficient of variation $(\mathrm{CV})$ was $8.8 \%$.

Plasma LH concentrations were determined by a double antibody RIA using reference preparation RP-3 and reagents in the rat LH kit obtained from the National Institute of Diabetes and Digestive and Kidney Diseases and Dr A.F. Parlow. To validate this assay for the Syrian hamster, samples from intact and castrated male plasma pools were assayed at five different dilutions. These results were compared to a standard curve generated with the $\mathrm{LH}$ reference preparation ranging from $0.8 \mathrm{ng}$ to $30 \mathrm{ng} / \mathrm{mL}$. $\mathrm{LH}$ values obtained from the diluted pools were parallel to the standard curve and maintained linearity throughout its range. All samples were run in duplicate in a single assay. Values are reported as nanogram equivalents of NIDDK-rLH-RP-3. The lower limit of detectability was $0.93 \mathrm{ng} / \mathrm{mL}$ and the intra-assay $\mathrm{CV}$ was $13.6 \%$.

\section{Statistical Analysis}

Two-way analysis of variance (ANOVA) was used to analyse the effects of age and steroid treatment on plasma testosterone concentrations, plasma LH concentrations, number of labelled cells, and mean grain area $\left(\mu \mathrm{m}^{2}\right.$ occupied by silver grains). Significant main effects were probed using Fisher's PLSD tests. The number of labelled cells and mean grain area were analysed separately for GnRH neurones within the tenia tecta, DBB/OVLT, MS, and cPOA. Although each treatment group consisted of 6 hamsters, actual sample sizes for the brain regional analysis of $\mathrm{GnRH}$ mRNA varied because of poor tissue quality resulting from occasional difficulties during sectioning or in situ hybridization. When sections from a particular brain region were not analysable, data from that region for that animal were eliminated from the analysis.

Because ANOVA revealed no significant age effects, data from adults and juveniles were combined for the frequency distribution and regression analyses. Kolmogorov-Smirnov two-sample tests were used to determine whether frequency distributions of cells categorized by intensity of silver grain labelling were different for testosterone-treated and control animals within each brain region. For this analysis, a P-value $\leq 0.001$ was required for statistical significance. Finally, using data from individual animals in all age and treatment groups, simple regression analyses were used to determine the correlation between plasma LH concentrations and mean silver grain area in each brain region. Except as noted above, $\mathrm{P}$-values $\leq 0.05$ were considered statistically significant.

\section{Results}

\section{Plasma hormone levels}

Plasma testosterone concentrations were undetectable $(<0.1 \mathrm{ng} / \mathrm{mL})$ in juvenile and adult castrates treated with blank pellets (Fig. 3A). At both ages, treatment with $2.5 \mathrm{mg}$ testosterone resulted in plasma hormone concentrations that were within adult physiological range $(1,17,20)$. Thus, there was a significant increase in plasma testosterone in castrates treated with $2.5 \mathrm{mg}$ testosterone $(\mathrm{P} \leq 0.05$, Fig. 3A). Plasma testosterone concentrations in testosterone-treated juveniles and adults were not significantly different.

A significant effect of treatment on LH plasma concentrations was found, with testosterone-treated castrates having lower plasma LH levels than blank-treated castrates $(\mathrm{P} \leq 0.05$, Fig. 3B). There was no interaction between age and testosterone on $\mathrm{LH}$, indicating that the $2.5 \mathrm{mg}$ dose of testosterone reduced $\mathrm{LH}$ concentrations to a similar degree in juvenile and adult castrates.

\section{Number of labelled cells}

Neither age nor hormone treatment significantly affected the number of labelled cells in any of the four brain regions analysed separately, or when regions were considered together (Table 1).

\section{Silver grain analysis}

Figure 4 shows labelled cells in representative adult castrates treated with either 0 or $2.5 \mathrm{mg}$ of testosterone. Approximately $100 \mathrm{GnRH}$ neurones were analysed in each animal (all labelled cells identified in the 1 -in-8 series of sections). Mean silver 


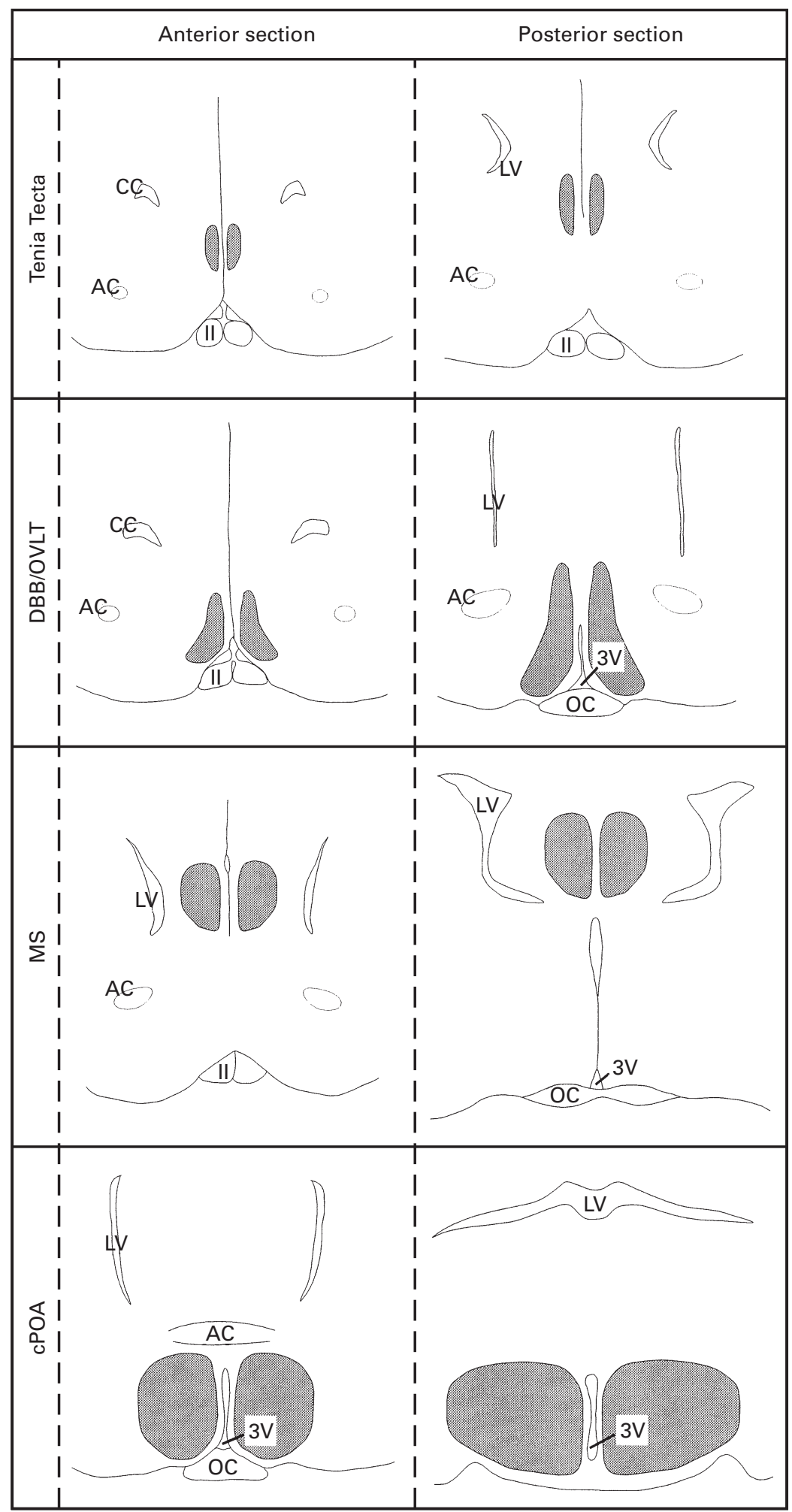

FIG. 2. Camera lucida drawings of the most anterior and posterior sections of the four brain regions analysed: tenia tecta, diagonal band of Broca/ organum vasculosum of the lamina terminalis (DBB/OVLT), medial septum (MS), and caudal preoptic area (cPOA). The area within which the GnRH cells reside is indicated by shading. Abbreviations: II, optic nerve; $3 \mathrm{~V}$, 3rd ventricle; AC, anterior commissure; CC, corpus callosum; LV, lateral ventricle; OC, optic chiasm. 
grain area values for each hamster were averaged within a treatment group for the statistical analyses. There was no effect of age or testosterone treatment on mean silver grain area when all brain regions were analysed together (juvenile $0 \mathrm{mg}$ testosterone, $6.96 \pm 0.79 \mu \mathrm{m}^{2}$; adult $0 \mathrm{mg}$ testosterone, $6.73 \pm 0.56 \mu^{2}$; juvenile $2.5 \mathrm{mg}$ testosterone, $5.81 \pm 0.76 \mu \mathrm{m}^{2}$;
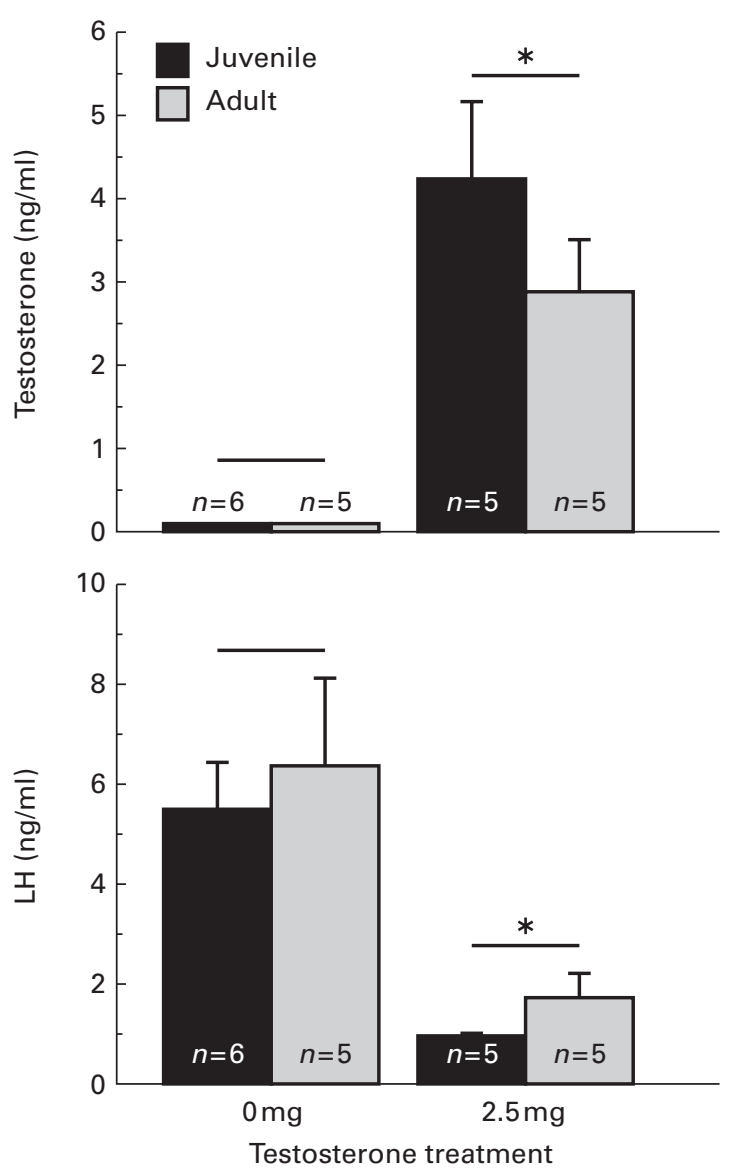

FIG. 3. Plasma testosterone (top panel) and LH (bottom panel) concentrations in juvenile and adult males following castration and treatment with 0 or $2.5 \mathrm{mg}$ testosterone. Asterisk and bars indicate a main effect of testosterone treatment on plasma testosterone and $\mathrm{LH}(\mathrm{P} \leq 0.05)$ and no interaction within age. Thus, hamsters treated with $2.5 \mathrm{mg}$ testosterone had significantly higher plasma testosterone than hamsters treated with $0 \mathrm{mg}$ testosterone (top panel). Hamsters treated with $2.5 \mathrm{mg}$ testosterone had significantly lower plasma LH than hamsters treated with $0 \mathrm{mg}$ testosterone (bottom panel). adult $2.5 \mathrm{mg}$ testosterone, $5.06 \pm 0.64 \mu \mathrm{m}^{2}$ ). When brain regions were analysed separately, there was a significant reduction in mean silver grain area with testosterone treatment only in the tenia tecta $(P \leq 0.05$, Fig. 5, top panel). This effect was independent of pubertal status. Smaller and nonsignificant trends toward decreased silver grain area in testosteronetreated castrates were observed in the DBB/OVLT, MS, and cPOA (Fig. 5, bottom three panels).

Because there was neither an effect of age nor an interaction between age and treatment on area covered by silver grains, labelled cells from juveniles and adults were pooled to create a frequency distribution based on mean silver grain area. In the tenia tecta and MS, the frequency distributions for vehicleand testosterone-treated groups were significantly different, indicating an increase in the proportion of lightly labelled cells (or a decrease in the proportion of heavily labelled cells) with testosterone treatment (Fig. $6, \mathrm{P} \leq 0.001$ ). The frequency distributions of cells within the DBB/OVLT and cPOA did not differ for testosterone and blank-treated hamsters.

\section{Regression analyses}

The relationship between plasma LH and GnRH mRNA in each brain region was examined by simple regression analyses of data from individuals in all treatment/age groups. There was a modest, but significant, positive correlation between plasma LH levels and mean silver grain area in the tenia tecta $(\mathrm{P} \leq 0.05$, Fig. 7 , top panel). In contrast, LH concentrations and mean grain area were not correlated in DBB/OVLT, MS, or cPOA (Fig. 7, bottom three panels).

\section{Discussion}

This study demonstrates that testosterone treatment results in brain region-dependent reductions in GnRH mRNA, as determined by analysis of in situ hybridization silver grain labelling. Reduced GnRH mRNA in the presence of testosterone was reflected by (1) a significant decrease in the area of neurones covered by silver grains in the tenia tecta, and (2) a significant shift toward a greater percentage of lightly labelled cells in both tenia tecta and medial septum. In the DBB/OVLT and cPOA, these indices of GnRH mRNA were unaffected by testosterone. Thus, regulation of GnRH mRNA by testosterone is most pronounced in tenia tecta neurones, intermediate in medial septum, and absent in DBB/OVLT and cPOA. We conclude that steroid negative-feedback regulation of the GnRH neuronal system includes modest reductions in

TABle 1. Mean $( \pm$ SEM) Number of GnRH mRNA Expressing Cells.

\begin{tabular}{|c|c|c|c|c|c|}
\hline \multirow[b]{2}{*}{ Treatment group } & \multicolumn{5}{|c|}{ Brain region (\# of labelled cells) } \\
\hline & Tenia tecta & DBB/OVLT & MS & cPOA & Total \\
\hline Juvenile ( $0 \mathrm{mg}$ testosterone) & $13.80 \pm 3.37$ & $35.33 \pm 7.47$ & $35.17 \pm 7.55$ & $10.40 \pm 0.6$ & $98.50 \pm 9.67$ \\
\hline Adult ( $0 \mathrm{mg}$ testosterone $)$ & $11.60 \pm 2.79$ & $47.40 \pm 3.72$ & $40.20 \pm 4.47$ & $10.80 \pm 3.5$ & $110.00 \pm 11.07$ \\
\hline Juvenile (2.5 $\mathrm{mg}$ testosterone) & $9.40 \pm 1.89$ & $31.40 \pm 8.62$ & $26.00 \pm 3.03$ & $8.25 \pm 1.97$ & $77.25 \pm 12.20$ \\
\hline Adult (2.5 mg testosterone) & $15.25 \pm 6.05$ & $41.25 \pm 5.63$ & $31.50 \pm 4.94$ & $7.60 \pm 1.6$ & $95.75 \pm 15.45$ \\
\hline
\end{tabular}


GnRH mRNA, particularly in rostral brain regions, but also involves other cellular mechanisms.

These data are in agreement with earlier reports that steroid negative feedback regulation of $\mathrm{GnRH}$ neurones is associated with a decrease in $\operatorname{GnRH}$ mRNA $(15,16,21)$. However, it is unlikely that steroid negative-feedback is exclusively exerted at the level of GnRH mRNA expression. First, the magnitude of the reduction in GnRH mRNA induced by steroid treatment in current and previous (15) studies is relatively modest compared with the magnitude of the reduction in $\mathrm{LH}$ secretion. Second, other studies report that castration results in either no change in GnRH mRNA (22-24) or in an increase in GnRH mRNA (25). Factors that potentially contribute to these different findings include mRNA detection methods, time between castration and hormone treatment, tissue collection methods, and brain regions analysed. Collectively, the literature suggests that steroid negative feedback

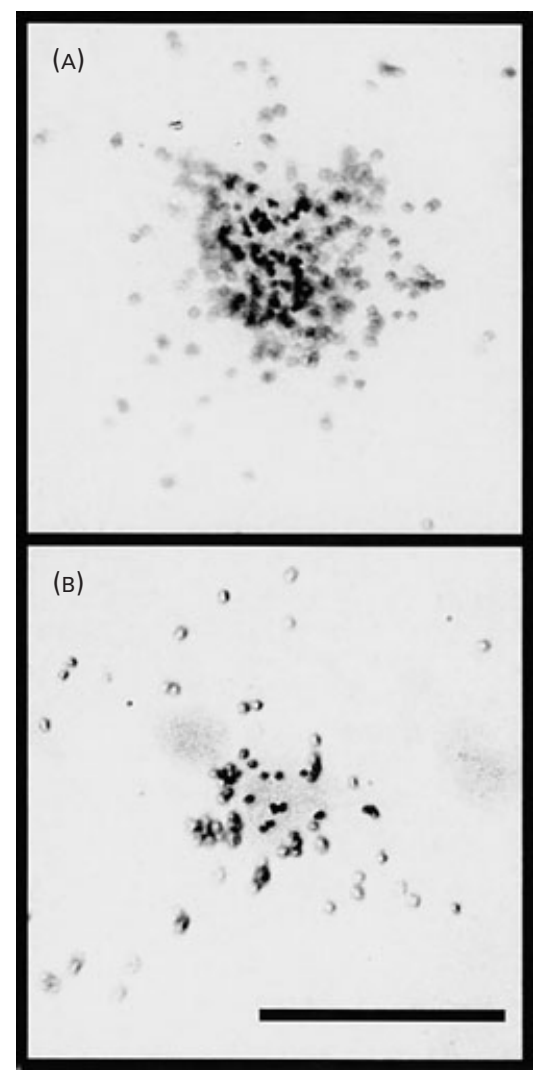

FIG. 4. Photomicrographs of labelled cells in the tenia tecta from castrated adults treated with $0 \mathrm{mg}$ testosterone (A) or $2.5 \mathrm{mg}$ testosterone (в). Only silver grains over the Nissl stain were measured (dark grains in plane of focus), providing a conservative estimate of the total silver grain staining associated with each cell. Bar, $20 \mu \mathrm{m}$.

Fig. 5. Mean grain area $\left(\mu \mathrm{m}^{2}\right)$ in the tenia tecta, DBB/OVLT, MS, and cPOA in castrates (collapsed across age) treated with 0 or $2.5 \mathrm{mg}$ of testosterone. Asterisk indicates a significant effect of treatment only in the tenia tecta $(\mathrm{P} \leq 0.05)$. Testosterone treatment significantly reduced $\mathrm{GnRH}$ mRNA mean grain area within this group of $\mathrm{GnRH}$ neurones.
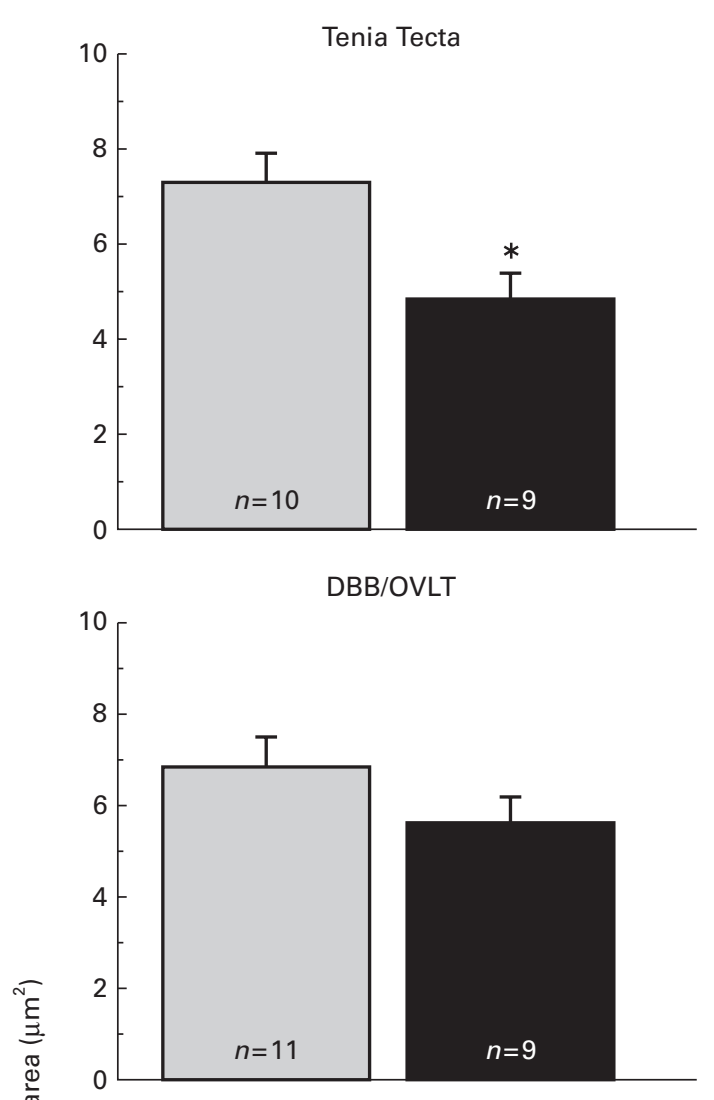

MS
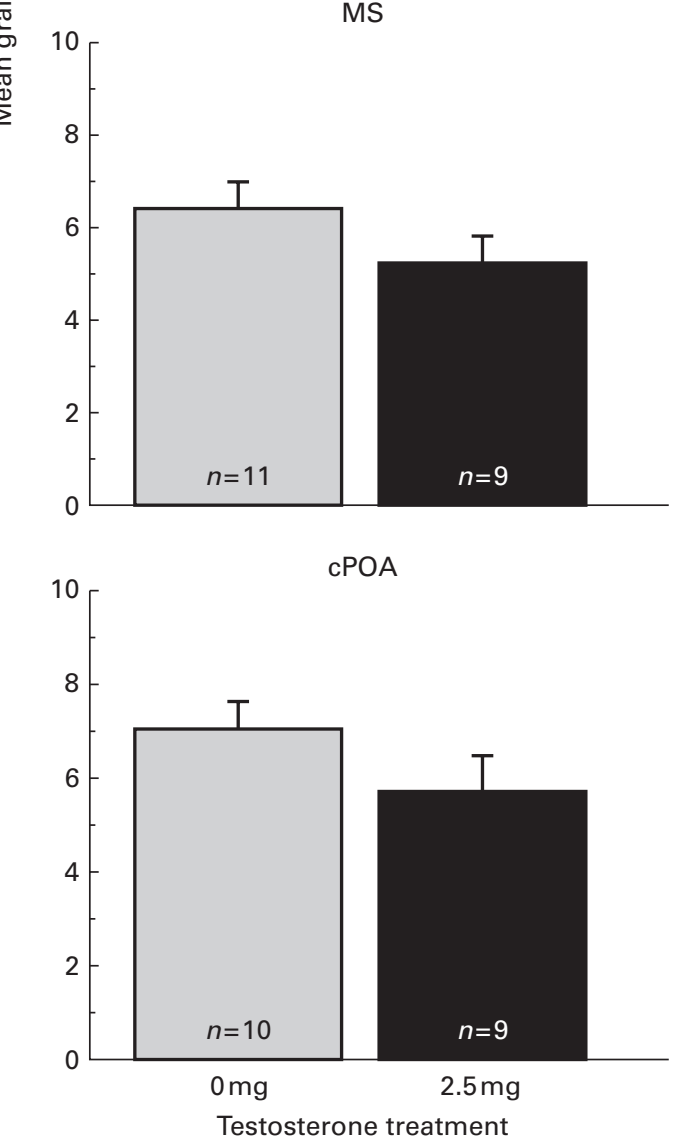

(C) 2002 Blackwell Science Ltd, Journal of Neuroendocrinology, 14, 375-383 

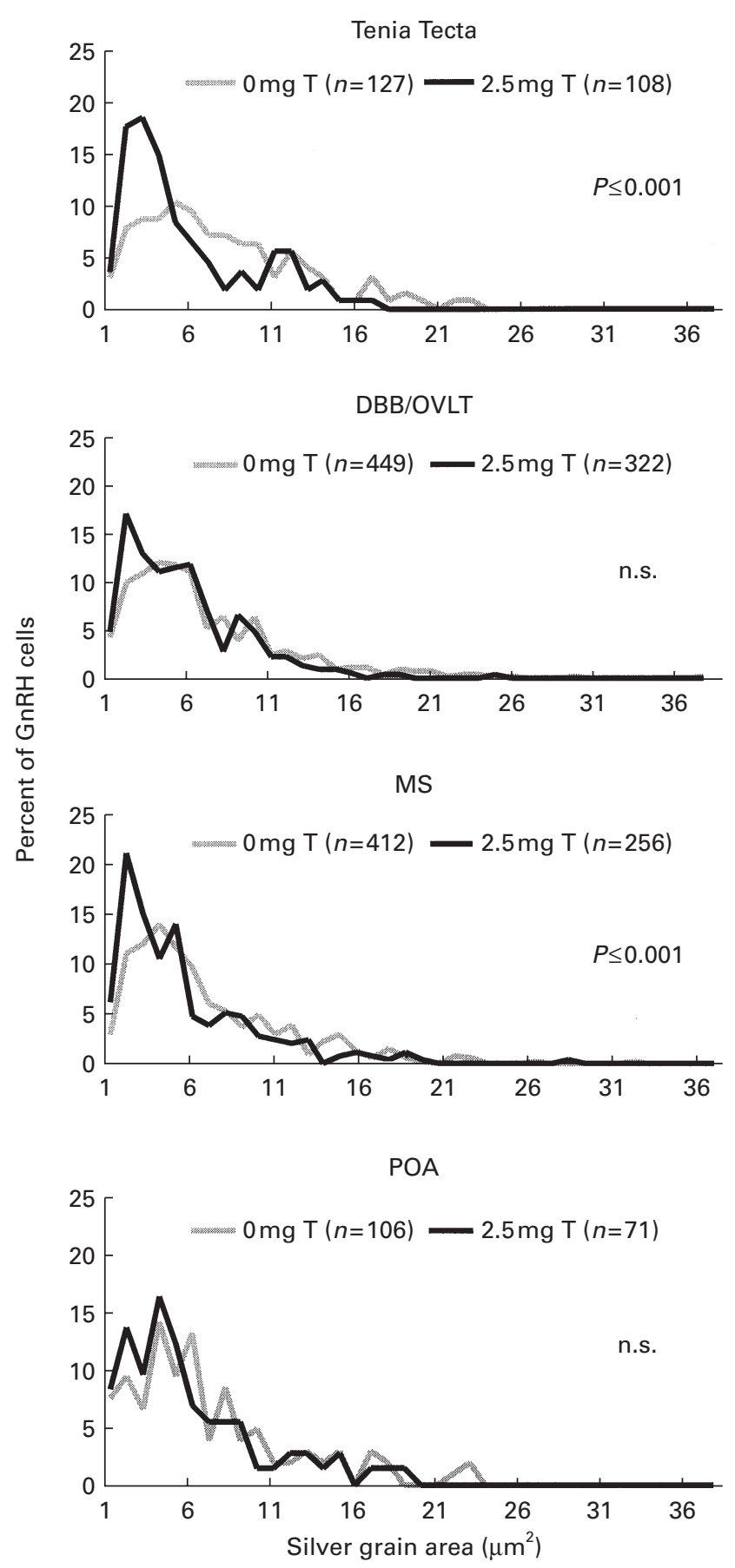

FIG. 6. Frequency distribution of the percentage of $\mathrm{GnRH}$ neurones within the tenia tecta, DBB/OVLT, MS, and cPOA in each category of GnRH mRNA grain area $\left(\mu \mathrm{m}^{2}\right)$. Mean grain area for each analysed cell was rounded to the nearest whole number and the cells were categorized into bins ranging from $1 \mu \mathrm{m}^{2}$ to $36 \mu \mathrm{m}^{2}$. The total number of cells for each treatment group determined n. Data from both juveniles and adults were included in the treatment groups. Frequency distributions for castrates and testosterone-treated males were significantly different $(\mathrm{P} \leq 0.001)$ only in the tenia tecta and MS. regulation of $\mathrm{GnRH}$ neurones is complex, occurs at multiple cellular levels in a brain region-dependent fashion, and is dynamic after experimental manipulation.

In the current study, the GnRH cells most affected by testosterone negative feedback were the tenia tecta $\mathrm{GnRH}$ cells. The population of GnRH neurones in the tenia tecta has not been as thoroughly studied as those in other forebrain and hypothalamic areas. In female musk shrews, tenia tecta GnRH cells have been strongly linked to the sensory-induced preovulatory gonadotropin surge evoked by interactions with a male, and the number of GnRH-immunoreactive cells in tenia tecta correlates with plasma concentrations of oestradiol $(10-12)$. The present study is the first to link tenia tecta neurones to steroid regulation of gonadotropin secretion in males, as GnRH mRNA was most robustly affected by testosterone in these cells, and also was positively correlated with plasma LH concentrations.

The number of GnRH neurones in the tenia tecta of the hamster is relatively small, only slightly larger than the size of the population of GnRH neurones in the cPOA and representing approximately $10-15 \%$ of the total population of GnRH cells. However, a small number of cells does not preclude an important role for them in the regulation of gonadotropin secretion. For example, studies in which GnRH neurones were implanted into the hypothalamus of the hypogonadal $(h p g)$ mutant mouse demonstrate that only a few GnRH neurones are sufficient to reinstate gonadotropin secretion and reproductive fertility (26). In addition, a general principle of the organization of the GnRH neuronal system is specialization with respect to afferent input and colocalization of neuropeptides and neurotransmitter receptors. For example, only 5-20\% of GnRH neurones appear to express NMDA receptors $(27,28)$, and only about $30 \%$ of $\mathrm{GnRH}$ neurones receive vasoactive intestinal polypeptide afferents (29). Thus, tenia tecta GnRH neurones may represent a population of median eminence-projecting cells in which steroid negativefeedback regulation occurs at the level of GnRH mRNA expression or stability. It will be important in future studies to characterize other phenotypic traits of this group of cells in order to understand their role in the HPG axis or other central roles. For example, are GnRH to GnRH contacts more prevalent within this population of cells, as is suggested by the position of GnRH cell bodies within a dense plexus of $\mathrm{GnRH}$ fibres in the tenia tecta?

We found no evidence that testosterone regulates $\mathrm{GnRH}$ mRNA in different populations of cells before and after puberty. We could not determine from this experiment whether the threshold for inhibition of GnRH mRNA increases in parallel with the increase in threshold for inhibition of $\mathrm{LH}$ following pubertal maturation. The dose of testosterone used in the present experiment resulted in nearly undetectable levels of LH in both juveniles and adults. Thus, while high testosterone levels clearly reduce $\mathrm{GnRH}$ mRNA in both prepubertal and adult males, it was not possible to learn whether pubertal status interacts with testosterone in the regulation of $\mathrm{GnRH}$ mRNA. Future work will determine whether doses of testosterone that differentially lower LH concentrations in juveniles and adults also differentially results in brain region-dependent reductions of GnRH mRNA at these two ages. 


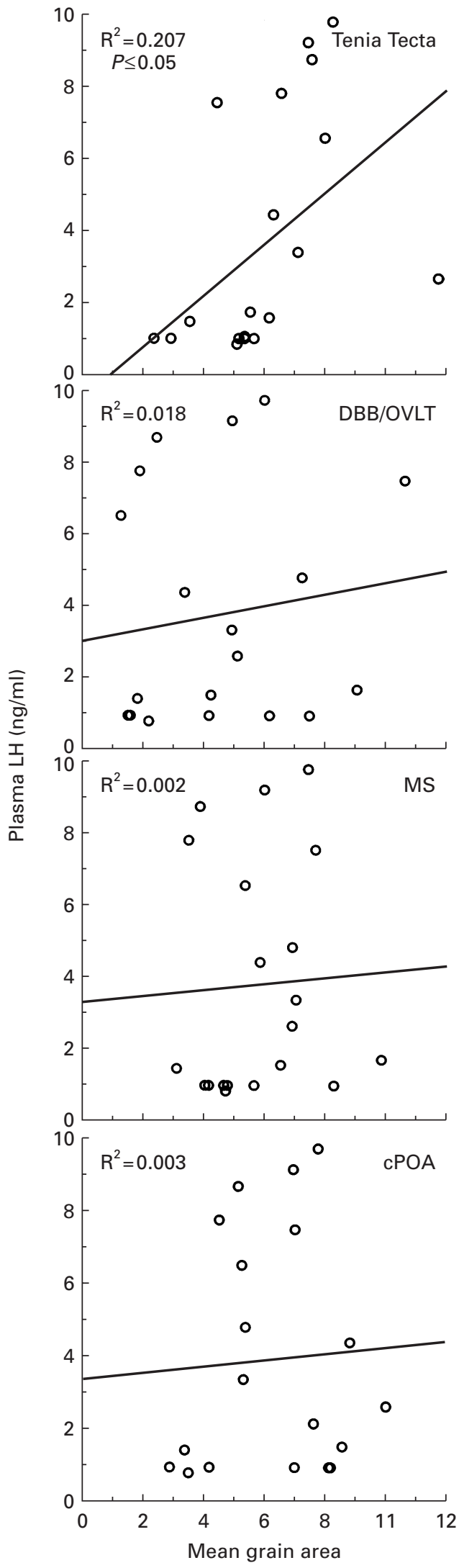

\section{Acknowledgements}

We thank Beckie Demo and Jane Venier for technical assistance. This work was supported by NSF IBN 9602169.

Accepted 31 January 2002

\section{References}

1 Sisk CL, Turek FW. Developmental time course of pubertal and photoperiodic changes in testosterone negative feedback on gonadotropin secretion in the golden hamster. Endocrinology 1983; 112: 1208-1216.

2 Hoffman GE, Lee WS, Attardi B, Yann V, Fitzsimmons MD. Luteinizing hormone-releasing hormone neurons express c-fos antigen after steroid activation. Endocrinology 1990; 126: 1736-1741.

3 Mitchell V, Bouret S, Prevot V, Jennes L, Beauvillain JC. Evidence for expression of galanin receptor Gal-R1 mRNA in certain gonadotropin releasing hormone neurones of the rostral preoptic area. J Neuroendocrinol 1999; 11: 805-812.

4 Prevot V, Bouret S, Croix D, Takumi T, Jennes L, Mitchell V, Beauvillain JC. Evidence that members of the TGFbeta superfamily play a role in regulation of the GnRH neuroendocrine axis: expression of a type I serine-threonine kinase receptor for TGRbeta and activin in $\mathrm{GnRH}$ neurones and hypothalamic areas of the female rat. J Neuroendocrinol 2000; 12: 665-670.

5 Wu TJ, Segal AZ, Miller GM, Gibson MJ, Silverman AJ. FOS expression in gonadotropin-releasing hormone neurons. Enhancement by steroid treatment and mating. Endocrinology 1992; 131: 2045-2050.

6 Jennes L, Stumpf WE. LHRH-systems in the brain of the golden hamster. Cell Tissue Res 1980; 209: 239-256.

7 Lehman MN, Newman SW, Silverman AJ. Luteinizing hormonereleasing hormone in the vomeronasal system and terminal nerve of the hamster. Ann NY Acad Sci 1987; 519: 229-240.

8 Richardson HN, Romeo RD, Sisk CL. Regional changes in GnRH immunoreactivity with puberty in the male Syrian hamster. Brain Res 1999; 817: 232-235.

9 Silverman AJ, Livne I, Witkin JW. The gonadotropin-releasing hormone $(\mathrm{GnRH})$, neuronal systems. Immunocytochemistry and in situ hybridization. In: Knobil E, Neill JD, eds. The Physiology of Reproduction. New York: Raven Press, 1994: 1683-1709.

10 Dellovade TL, Rissman EF. Gonadotropin-releasing hormoneimmunoreactive cell numbers change in response to social interactions. Endocrinology 1994; 134: 2189-2197.

11 Dellovade TL, Ottinger MA, Rissman EF. Mating alters gonadotropinreleasing hormone cell number and content. Endocrinology 1995; 136: $1648-1657$.

12 Dellovade TL, Hunter E, Rissman EF. Interactions with males promote rapid changes in gonadotropin-releasing hormone immunoreactive cells. Neuroendocrinology 1995; 62: 385-395.

13 Petersen SL, McCrone S, Keller M, Shores S. Effects of estrogen and progesterone on luteinizing hormone-releasing hormone messenger ribonucleic acid levels: consideration of temporal and neuroanatomical variables. Endocrinology 1995; 136: 3604-3610.

14 Porkka-Heiskanen T, Urban JH, Turek FW, Levine JE. Gene expression in a subpopulation of luteinizing hormone-releasing hormone (LHRH) neurons prior to the preovulatory gonadotropin surge. $J$ Neurosci 1994; 14: $5548-5558$.

15 Spratt DP, Herbison AE. Regulation of preoptic area gonadotrophinreleasing hormone $(\mathrm{GnRH})$ mRNA expression by gonadal steroids in the long-term gonadectomized male rat. Brain Res Mol Brain Res 1997; 47: $125-133$.

16 Selmanoff M, Shu C, Petersen SL, Barraclough CA, Zoeller RT. Single cell levels of hypothalamic messenger ribonucleic acid encoding luteinizing hormone-releasing hormone in intact, castrated, and hyperprolactinemic male rats. Endocrinology 1991; 128: 459-466.

FIG. 7. Simple regression analyses of GnRH mRNA mean grain area $\left(\mu \mathrm{m}^{2}\right)$ and plasma LH for the tenia tecta, DBB/OVLT, MS, and cPOA. All age and treatment groups are represented in these analyses and each dot represents data from an individual animal. There was a significant correlation $(\mathrm{P} \leq 0.05)$ between plasma $\mathrm{LH}$ and $\mathrm{GnRH}$ mRNA mean grain area only within the tenia tecta. 
17 Parfitt DB, Thompson RC, Richardson HN, Romeo RD, Sisk CL. GnRH mRNA increases with puberty in the male Syrian hamster brain. J Neuroendocrinol 1999; 11: 621-627.

18 Morin LP, Wood RI. Hamster Atlas. A Stereotaxic Atlas of the Golden Hamster Brain. San Diego: Academic Press, Inc., 2001.

19 Paxinos G, Watson C. The rat brain in stereotaxic coordinates, 2nd edn. San Diego: Academic Press, Inc., 1986.

20 Meek LR, Romeo RD, Novak CM, Sisk CL. Actions of testosterone in prepubertal and postpubertal male hamsters: dissociation of effects on reproductive behavior and brain androgen receptor immunoreactivity. Horm Behav 1997; 31: 75-88.

21 Wray S, Zoeller RT, Gainer H. Differential effects of estrogen on luteinizing hormone-releasing hormone gene expression in slice explant cultures prepared from specific rat forebrain regions. Mol Endocrinol 1989; 3: 1197-1206.

22 Malik KF, Silverman AJ, Morrell JI. Gonadotropin-releasing hormone mRNA in the rat. Distribution and neuronal content over the estrous cycle and after castration of males. Anat Rec 1991; 231: 457-466.

23 Ronchi E, Krey LC, Pfaff DW. Steady state analysis of hypothalamic GnRH mRNA levels in male Syrian hamsters: influences of photoperiod and androgen. Neuroendocrinology 1992; 55: 146-155.
24 Wiemann JN, Clifton DK, Steiner RA. Gonadotropin-releasing hormone messenger ribonucleic acid levels are unaltered with changes in the gonadal hormone milieu of the adult male rat. Endocrinology 1990; 127: 523-532.

25 Park Y, Park SD, Cho WK, Kim K. Testosterone stimulates LH-RH-like mRNA level in the rat hypothalamus. Brain Res 1988; 451: $255-260$.

26 Gibson MJ, Krieger DT, Charlton HM, Zimmerman EA, Silverman AJ, Perlow MJ. Mating and pregnancy can occur in genetically hypogonadal mice with preoptic area brain grafts. Science 1984; 225: 949-951.

27 Abbud R, Smith MS. Do GnRH neurons express the gene for the NMDA receptor? Brain Res 1995; 690: 117-120.

28 Gore AC, Wu TJ, Rosenberg JJ, Roberts JL. Gonadotropin-releasing hormone and NMDA receptor gene expression and colocalization change during puberty in female rats. J Neurosci 1996; 16: 5281-5289.

29 van der Beek EM, van Oudheusden HJ, Buijs RM, van der Donk HA, Vandon Hurk R, Wiegant VM. Preferential induction of c-fos immunoreactivity in vasoactive intestinal polypeptide-innervated gonadotropin-releasing hormone neurons during a steroid-induced luteinizing hormone surge in the female rat. Endocrinology 1994; 134: 2636-2644. 